\title{
DAMPAK KEBERADAAN PASAR MODREN TERHADAP KINERJA EKONOMI REGIONAL
}

\author{
Rasidin Karo-Karo Sitepu \\ Fakultas Pertanian Universitas Islam Sumatare Utara-Medan \\ E-mail: rasid888@yahoo.com
}

\begin{abstract}
The objective of study is to analyze the impact of modern market presence to performance of regional economic. Specification model using simultaneous equations and is suspected by the method of two stages least Squares. Using secondary data for series from 1980 to 2010. The results showed that the presence of a modern market significantly negative effect on the turnover of MSMEs trade sector. Conversely a positive impact on MSME sector of agriculture and manufacture. Scenario modern market presence is significantly negative effect on traditional markets. Number of traditional markets and local government original receipt (PAD) will be decrease. However, overall gross regional domestic product (PDRB) and purchasing power parity are increased, while the number of unemployed decreased. To reduce the negative impact of modern market presence can be done by restricted the license of modern markets, increased access to capital, increased market access by doing a partnership with a modern market.
\end{abstract}

Key words: Modern Market, Tradisional Market, MSMEs, Partnership

\section{PENDAHULUAN}

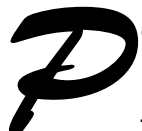
asar dapat didefinisikan sebagai area tempat jual beli barang dengan jumlah penjual lebih dari satu, baik yang disebut sebagai pusat perbelanjaan, pasar tradisional, pertokoan, mall, plasa, pusat perdagangan maupun sebutan lainnya. Dalam Peraturan Menteri Perdagangan RI No 53/M-DAG/PER/12/2008, disebutkan bahwa Toko Modern adalah toko dengan sistem pelayanan mandiri, menjual berbagai jenis barang secara eceran yang berbentuk Minimarket, Supermarket, Department Store, Hypermarket ataupun grosir yang berbentuk perkulakan.

Sinaga (2006) mengatakan bahwa pasar modern adalah pasar yang dikelola dengan manajemen modern, umumnya terdapat di kawasan perkotaan, sebagai penyedia barang dan jasa dengan mutu dan pelayanan yang baik kepada konsumen (umumnya anggota masyarakat kelas menengah ke atas). Pasar modern antara lain QE Journal | Vol.01 - No.01 - 1 
mall, supermarket, departement store, shopping centre, waralaba, toko mini swalayan, pasar serba ada, toko serba ada dan sebagainya. Barang yang dijual disini memiliki variasi jenis yang beragam. Selain menyediakan barang-barang lokal, pasar modernjuga menyediakan barang impor. Barang yang dijual mempunyai kualitas yang relatif lebih terjamin karena melalui penyeleksian terlebih dahulu secara ketatmenyediakan barang impor. Barang yang dijual mempunyai kualitas yang relatif lebih terjamin karena melalui penyeleksian terlebih dahulu secara ketat sehingga barang yang rijek/tidak memenuhi persyaratan klasifikasi akan ditolak. Secara kuantitas, pasar modern umumnya mempunyai persediaan barang di gudang yang terukur. Dari segi harga, pasar modern memiliki label harga yang pasti (tercantum harga sebelum dan setelah dikenakan pajak). Pasar modern juga memberikan pelayanan yang baik.

Supermarket telah ada sejak 1970-an namun masih terkonsentrasi di kota-kota besar. Masukknay milik Supermarket asing ke Indonesia pada akhir 1990-an semenjak kebijakan investasi asing langsung dalam sektor usaha ritel dibuka pada 1998. Persaingan yang ketat mendorong munculmya supermarket di kota yang lebih kecil dalam rangka untuk mencari pelanggan baru dan terjadinya perang harga. Supermarket Indonesia hanya melayani masyarakat kelas menengah-atas era 1980-an dan awal 1990-an (CPIS 1994), dan berkembangnya supermarket hingga ke kota kecil dan adanya strategi pemotongan harga memungkinkan konsumen kelas menengahbawah untuk mengakses supermarket. Persoalan ini tentu juga dialami di negara berkembang lainnya (Reardon et al 2003; Collett \& Wallace 2006), seperti yang dialami oleh Kabupaten Subang.

Pertumbuhan supermarket dilihat dari pangsa pasar cukup mengejutkan. World Bank (2007) menunjukkan bahwa pada 1999 pasar modern hanya meliputi 11\% dari total pangsa pasar bahan pangan. Menjelang 2004, jumlah tersebut meningkat tiga kali lipat menjadi 30\%. Terkait dengan tingkat penjualan, studi tersebut menemukan bahwa jumlah penjualan di supermarket bertumbuh rata-rata $15 \%$, sementara penjualan di ritel tradisional menurun $2 \%$ per tahun. Kendati persaingan antarsupermarket secara teoretis menguntungkan konsumen, dan mungkin perekonomian secara keseluruhan, namun relative sedikit diketahui dampaknya terhadap pasar tradisional dan pelaku UMKM secara keseluruhan.

Nielson, (2003) menyatakan bahwa pasar modern telah tumbuh sebesar 31,4\%, dan sejalan dengan itu, pasar tradisional telah tumbuh secara negatif sebesar $8 \%$. Berdasarkan kenyataan ini maka pasar tradisional akan habis dalam kurun waktu sekitar 12 tahun yang akan datang, sehingga perlu adanya langkah preventif untuk menjaga kelangsungan pasar tradisional termasuk kelangsungan usaha perdagangan (ritel) yang dikelola oleh koperasi dan UKM.

Suryadharma, et.all (2007) dalam penelitiannya tentang Dampak Supermarket terhadap Kebijakan Pasar dan Pedagang Ritel Tradisional di Daerah Perkotaan di Indonesia, mengungkapkan bahwa dari tiga indikator kinerja pasar tradisional (keuntungan, omzet, dan jumlah pegawai), supermarket secara statistik hanya berdampak pada jumlah pegawai yang dipekerjakan oleh pedagang pasar tradisional. Hasilnya menunjukkan bahwa jumlah pegawai yang dipekerjakan oleh pedagang pasartradisional menjadi berkurang bila keberadaan pasar dekat dengan supermarket, 
dan demikian sebaliknya. Hasil ini kemudian ditegaskan oleh temuan analisis kualitatif bahwa supermarket bukanlah penyebab utama kelesuan usaha yang dialami pedagang pasar tradisional. Para pedagang, pengelola pasar, wakil APPSI semuanya menegaskan bahwa langkah utama yang harus dilakukan demi menjamin keberadaan pedagang pasar tradisional adalah perbaikan infrastruktur pasar tradisional, pengorganisasian para PKL, dan pelaksanaan praktik pengelolaan pasar yang lebih baik. Para pedagang secara eksplisit mengungkapkan keyakinan mereka bahwa supermarket tidak akan menyingkirkan usaha mereka jika syarat tersebut di atas dapat dipenuhi. Sementara itu, terdapat bukti nyata bahwa sebagian pedagang telah menutup usaha dagangnya selama tiga tahun yang lalu. Alasan untuk hal ini bersifat lebih kompleks dari sekadar karena hadirnya supermarket semata. Kebanyakan penutupan usaha erat berkaitan dengan persoalan internal pasar dan persoalan pribadi. Selain itu, pedagang yang pelanggan utamanya bukan rumah tangga dan telah membina hubungan yang baik dengan pelanggan selama waktu yang lama berkemungkinan lebih besar untuk bertahan dalam usahanya.

Globalisasi ekonomi juga berdampak pada masuknya investor asing maupun lokal (Luar Kabupaten Subang). Salah satu yang saat ini cukup marak dan tersebar di setiap kabupaten adalah berkembangnya pasar Modern (seperti Supermarket, Hypermarket) di ibu koata kabupaten dan minimarket di lbu Kota Kecamatan, yang keberadaanya tidak dapat dicegah karena tuntutan globalisasi. Tidak dapat dipungkiri bahwa pasar modern dewasa ini sudah menjadi tuntutann dan konsekuensi dari gaya hidup modern yang berkembang di masyarakat. Tempat-tempat tersebut menjanjikan tempat belanja yang nyaman, bersih dengan harga yang tidak kalah menariknya.

Kehadiran pasar modern tersebut menjadi dilemma bagi pemerintah Daerah Kabupaten Subang, karena pasar modern disatu pihak menghambat pertumbuhan pasar tradisional dan UMKM, karean dari berbagai studi mengindikasikan adanya pengaruh negatif bagi pelaku UMKM, terutama bagi UMKM yang bergerak disektor perdagangan. Disisi lain, kehadiran pasar modern, justru menjadi indikator kemajuan daerah Kabupaten Subang. Dari latar belakang dan permasalahan, penelitian ini bertujuan untuk mengetahui dampak keberadaan pasar modern terahdap kinerja ekonomi daerah Kabupaten Subang.

\section{METODOLOGI}

\section{PROSEDUR DAN KERANGKA OPERASIONAL MODEL}

Metode analisis data untuk menjawab tujuan penelitian secara umum adalah dengan membangun permodelan ekonometrika. Permodelan ekonometrika digunakan untuk menjawab faktor-faktor yang mempengaruhi perkembangan UMKM dan pasar trandisional, dan sekaligus untuk menganaslis kondisi makro ekonomi yang berkaitan dengan adanya pasar modern serta pengaruhnya terhadap kinerja ekonomi daerah (Growth, PDRB, PAD, dan peningkatan Dayabeli) Kabupaten Subang. Prosedur dan kerangka operasional model ditampilkan Gambar 1. 


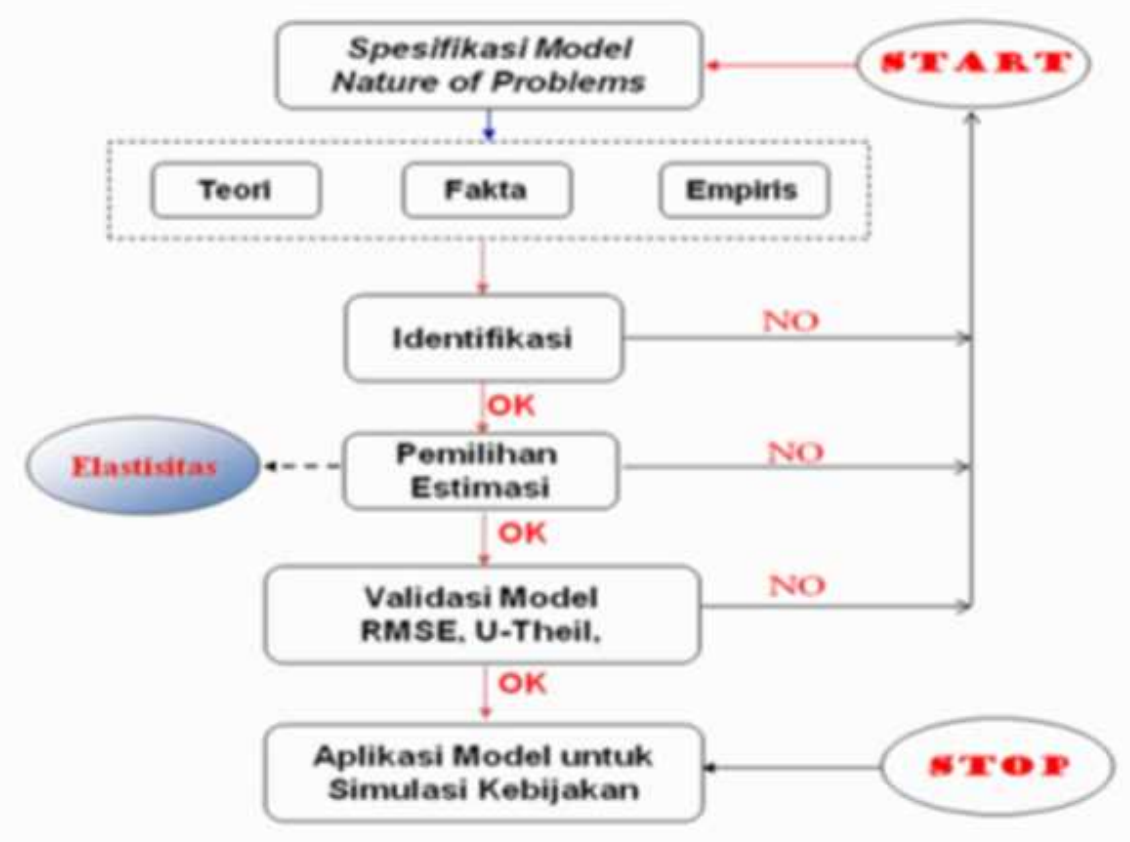

Gambar 1. Prosedur dan Kerangka Operasional Model

Tahapan untuk membangun model diawali dari sebuah persoalan yang terkait dengan pasar tradisional dan UMKM yang mengacu pada konsep teori, fakta dan empiris. Setelah spesifkasi model ditentukan, maka selanjutnya model akan diidentifikasi dan akan ditentukan pemilihan teknik estimasi yang sesuai. Jika model telah sesuai dengan harapan, selanjut keakurasian model akan diuji, menggunakan indikator statistik U-Theil dan root mean square error (RMSPE). Jika hal ini telah terpenuhi maka dapat dilakukan proses untuk melakukan simulasi dan analisis dampak terhadap keberadaan pasar modern terhadap kinjer ekonomi daerah Kabupaten Subang. Lebih detail permodelan ekonometrik akan diuraikan seperti berikut ini.

\section{SPEFISIKASI MODEL}

Dari hasil spesifikasi model, secara umum model dampak pasar modern terhadap UMKM Kabupaten Subang yang dibangun 11 persamaan, yang teridiri dari 10 persamaan perilaku dan 1 persamaan identitas. Secara spesifik fungsi untuk setiap variable endogen di setiap persamaan perilaku ditampilkan pada bagian berikut ini, yaitu:

$$
\begin{array}{ll}
Y_{1} & =\alpha_{0}+\alpha_{1} L_{1}+\alpha_{1} R_{1}+\alpha_{3} K+e_{1} \\
Y_{3} & =\beta_{0}+\beta_{1} L_{1}+\beta_{2} R_{1}+\beta_{3} K+e_{2} \\
Y_{6} & =\chi_{0}+\chi_{1} L_{1}+\chi_{2} R_{1}+\chi_{3} K+e_{3} \\
G D P & =Y_{1}+Y_{3}+Y_{6}+Y_{L} \\
R_{1} & =\delta_{0}+\delta_{1} Y_{1}+\delta_{2} P M+e_{4}
\end{array}
$$




$$
\begin{array}{ll}
R_{3} & =\phi_{0}+\phi_{1} Y_{3}+\phi_{2}(P M+P T)+e_{5} \\
R_{6} & =\gamma_{0}+\gamma_{1} Y_{6}+\gamma_{2} P M+e_{6} \\
P T & =\eta_{0}+\eta_{1} P M+\eta_{2} P O P+e_{7} \\
P A D & =\varphi_{0}+\varphi_{1} P T+\varphi_{2}(P M+P T)+\varphi_{2} G D P+e_{8} \\
I & =\lambda_{0}+\lambda_{1} G D P+\lambda_{2} I N F+e_{9} \\
U & =\mu_{0}+\mu_{1} G D P+\mu_{2} I N F+e_{10}
\end{array}
$$

Dimana:

$$
\begin{array}{ll}
\mathrm{e}_{\mathrm{i}} & =\text { error term dimana } i=1,2,3, \ldots, 10 \\
\mathrm{Y}_{1} & =\text { Output Sektor Pertanian (PDRB Sektor Pertanian) } \\
\mathrm{Y}_{3} & =\text { Output Sektor Industri (PDRB Sektor Industri) } \\
\mathrm{Y}_{6} & =\text { Output Sektor Perdagangan (PDRB Sektor Perdagangan) } \\
\mathrm{L}_{1} & =\text { Jumlah tenaga kerja Sektor Pertanian (PDRB Sektor Pertanian) } \\
\mathrm{L}_{3} & =\text { Jumlah tenaga kerja Sektor Industri (PDRB Sektor Industri) } \\
\mathrm{L}_{6} & =\text { Jumlah tenaga kerja Sektor Perdagangan (PDRB Sektor Perdagangan) } \\
\mathrm{R}_{1} & =\text { Nilai Omzet UMKM di Sektor Pertanian } \\
\mathrm{R}_{3} & =\text { Nilai Omzet UMKM di Sektor Idustri Pengolahan } \\
\mathrm{R}_{6} & =\text { Nilai Omzet UMKM di Sektor Perdagangan } \\
\mathrm{K}_{1} & =\text { Nilai Kredit Usaha UMKM di Sektor Pertanian } \\
\mathrm{K}_{3} & =\text { Nilai Kredit Usaha UMKM di Sektor Industri Pengolahan } \\
\mathrm{K}_{6} & =\text { Nilai Kredit Usaha UMKM di Sektor Perdagangan } \\
\mathrm{GDP} & =\text { PDRB Kabupaten Subang } \\
\mathrm{PT} & =\text { Jumlah Pasar Tradisional di Kabupaten Subang } \\
\mathrm{PM} & =\text { Jumlah Pasar Modern di Kabupaten Subang } \\
\mathrm{POP} & =\text { Jumlah penduduk Kabupaten Subang } \\
\mathrm{PAD} & =\text { Pendapatan Asli Daerah Kabupaten Subang } \\
\text { INF } & =\text { Tingkat Inflasi yang diproxy dari GDP Deflator }
\end{array}
$$

Model yang dibangun terdiri dari 11 persamaan atau 11 peubah endogen (G), dan 7 peubah eksogen. Sehingga total peubah dalam model (K) adalah 18 variabel, jumlah peubah dalam persamaan (M) adalah 3 variabel. Maka berdasarkan kriteria order condition:

$$
(K-M)>(G-1)
$$

maka setiap persamaan struktural yang ada dalam model adalah overidentified.Karena hasil identifikasi adalah overidentified, maka metode pendugaan model yang digunakan adalah 2SLS dengan beberapa pertimbangan, yaitu penerapan 2SLS menghasilkan taksiran yang konsisten, lebih sederhana dan lebih mudah, dan tidak sensitif terhadap kesalahan pengukuran maupun kesalahan spesifikasi model (Gujarati, 1999).

Untuk mengetahui apakah model cukup valid untuk membuat suatu simulasi alternatif kebijakan, maka perlu dilakukan suatu validasi model, dengan tujuan untuk 
manganalisis sejauhmana model tersebut dapat mewakili dunia nyata. Dalam kajian ini, kriteria statistik untuk validasi nilai pendugaan model ekonometrika yang digunakan adalah: Root Means Square Error (RMSE), dan Theil's Inequality Coefficient (U) (Pindyck and Rubinfield, 1991). Kriteria-kriteria dirumuskan sebagai berikut:

$$
U=\frac{\sqrt{\frac{1}{n} \sum_{t=1}^{n}\left(Y_{t}^{s}-Y_{t}^{a}\right)^{2}}}{\sqrt{\frac{1}{n} \sum_{t=1}^{n}\left(Y_{t}^{s}\right)^{2}+\sqrt{\frac{1}{n} \sum_{t=1}^{n}\left(Y_{t}^{a}\right)^{2}}}} \text { dan RMSE }=\sqrt{\frac{1}{n} \sum_{t=1}^{n}\left(Y_{t}^{s}-Y_{t}^{a}\right)^{2}}
$$

dimana:

$$
\begin{array}{ll}
Y_{t}^{s} & =\text { nilai hasil simulasi dasar dari variabel observasi } \\
Y_{t}^{a} & =\text { nilai aktual variabel observasi } \\
\mathrm{n} & =\text { jumlah periode observasi }
\end{array}
$$

Statistik RMSPE digunakan untuk mengukur seberapa jauh nilai-nilai peubah endogen hasil pendugaan menyimpang dari alur nilai-nilai aktualnya dalam ukuran relatif (persen), atau seberapa dekat nilai dugaan itu mengikuti perkembangan nilai aktualnya. Sedangikan nilai statistik $U$ bermanfaat untuk mengetahui kemampuan model untuk analisis simulasi peramalan. Nilai koefisien Theil $(U)$ berkisar antara 1 dan 0 . Jika $U=0$ maka pendugaan model sempurna, jika $U=1$ maka pendugaan model naif. Pada dasarnya makin kecil nilai RMSPE dan U-Theil's dan makin besar nilai $\mathrm{R}^{2}$, maka pendugaan model semakin baik.

\section{HASIL DAN PEMBAHASAN HASIL KERAGAAN MODEL}

Hasil estimasi model Kajian Keberadaan Pasar Modern terhadap Tingkat Pertumbuhan UKM di Kabupaten Subang secara umum dapat dikatakan baik, hal ini ditunjukkan oleh nilai koefisien determinasinya $\left(R^{2}\right)$ dari masing-masing persamaan perilaku yaitu berkisar antara 0.54 sampai dengan 0.96 . Hal ini menunjukkan bahwa secara umum peubah-peubah penjelas (exogenous variables) yang ada di dalam persamaan perilaku mampu menjelaskan dengan baik perilaku peubah endogen.

Dari indicator statistic diketahui bawah variasi variabel penjelas dalam setiap persamaan perilaku secara bersama-sama mampu menjelaskan dengan baik variasi peubah endogennya, disamping itu setiap persamaan struktural mempunyai besaran parameter dan tandanya sesuai dengan harapan dan cukup logis dari sudut pandang teori ekonomi (a priori economic), meskipun demikian masih terdapat beberapa explanatory variables yang tidak signifikan secara statistik, dalam arti bahwa secara individu variabel tersebut tidak berbeda nyata dengan nol mempengaruhi variabel endogennya. Nilai statistik-t, digunakan untuk menguji apakah masing-masing variabel penjelas berpengarauh nyata terhadap variabel endogennya. Dalam studi ini taraf $\alpha$ yang digunakan cukup fleksibel yaitu dengan taraf $\alpha=0.15$. 
Berdasarkan hasil uji statistik durbin-w (dw), terdapat sejumlah persamaan yang mengalami masalah serial korelasi, terlepas dari ada tidaknya masalah serial korelasi yang serius, Pindyck dan Rubinfeld (1991) membuktikan bahwa masalah serial korelasi hanya mengurangi efisiensi pendugaan parameter dan serial korelasi tidak menimbulkan bias parameter regresi, oleh karena itu, hasil pendugaan model dalam kajian ini dapat dinyatakan cukup representatif dalam menggambarkan fenomena model dampak pasar modert terhadap pertumbuhan UMKM.

$$
\begin{gathered}
\hat{y}_{1}=-0.064+0.516 L_{1 t}+0.524 R_{1 t}+0.748 K_{1 t} R^{2}=0.9689, \text { MSE }=0.0122 \\
(0.42) \quad \text { (0.73) }
\end{gathered}
$$

Dari hasil estimasi output sektor pertanian (persamaan 12) menunjukkan bahwa yang paling menonjol untuk mendorong omzet sektor pertnaian adalah pemberian kredit UMKM, dan hal ini secara statistic berbeda nyata dengan nol pada taraf kepercayaan 90 persen. Sedangkan jumlah tenaga kerja dan besar omzet di sektor pertanian meskipun arahnya positif tetapi tidak signifikan secara statistik.

$$
\hat{y}_{3}=-4.12+1.56 L_{3 t}+3.142 R_{3 t}+0.05 K_{3 t} \quad R^{2}=0.9595, M S E=0.0472
$$

Sedangkan hasil estimasi output sektor Industri Pengolahan (persamaan 13), jumlah tenaga kerja dan besarnya omzet di sektor tersebut akan sangat mempengaruhi besarnya nilai output sektor industri pengolahan. Kedua variable jumlah tenaga kerja dan omzet berpengaruh nyata secara positif terhadap perkembangan output sektor industri pengolahan. Sedangkan pemberian kredit meskipun secara ekonomi memberikan arah positif tetapi secara statistik tidak berbeda nyata dengan nol pada taraf kepercayaan 95 persen

$$
\begin{gathered}
\hat{y}_{6}=1.362+0.171 L_{6 t}+0.604 R_{6 t}+0.339 K_{6 t} \\
\text { (0.95) } \quad R^{2}=0.9211, \text { MSE=0.0203 } \quad \text { (3.24) } \quad \text { (3.72) }
\end{gathered}
$$

Besaran output sektor perdagangan (persamaan 14) dipengaruhi secara positif oleh jumlah omzet dan kredit UMKM dan kedua variable tersebut signifikan secara statistic. Sedangkan jumlah tenaga kerja secara statistic tidak berpengaruh nyata terhadap besaran perubahan output sektor perdagangan. Besaran omzet UMKM di sektor pertanian sangat dipengaruhi oleh besaran nilai output sektor pertanian dan jumlah pasar modern. Perubahan omzet sektor pertanian terhadap perubahan output akan searah dan signifikan secara statistik.

$$
\hat{R}_{1}=6.029+0.336 Y_{6 t}+0.075 P M_{t} \quad R^{2}=0.8712, M S E=0.0159
$$

Yang menarik adalah kehadiran pasar modern bagi UMKM sektor pertanian memberikan pengaruh yang positif dan signifikan pada taraf kepercayaan 85 persen. Ini menunjukkan bahwa semakin berkembang pasar modern omzet pertanian juga akan mengalami peningkatan. Dari penjelasan ini dapat diketahui bahwa UMKM yang 
bergerak di sektor pertanian akan saling melengkapi (complement) dengn kehadiran pasar modern (Persamaan 15).

$$
\hat{R}_{3}=7.667+0.053 Y_{3 t}+0.670\left(P M_{t}+P T_{t}\right) \quad R^{2}=0.9038, \quad M S E=0.0123
$$

Hal yang sama juga terjadi pada industri sektor pengolahan, dimana kehadiran pasar modern signifikan bagi penerimaan omzet UMKM sektor industri pengolahan. Persamaan (16) terlihat bahwa jumlah pasar modern akan berpengaruh secara positif terhadap perkembangan omzet industri pengolahan.

$$
\hat{R}_{6}=-2.633+0.974 Y_{6 t}-0.074 P M_{t} \quad R^{2}=0.8295, M S E=0.0260
$$

$$
\text { (4.58) (-1.34) }
$$

Tetapi berbeda halnya yang terjadi terhadap sektor perdagangan, dimana kehadiran pasar modern memberikan pengaruh yang negative bagi omzet UMKM sektor perdagangan (Persamaan 17). Artinya semakin berkembang pasar modern, maka omzet UMKM sektor perdagangan akan semakin menurun. Dapat disimpulkan sementara bahwa semakin berkembang pasar modern omzet sektor perdagangan akan mengalami penurunan. Dari penjelasan ini dapat diketahui bahwa UMKM yang bergerak di sektor perdagangan akan saling bersaing (competitor) dengan kehadiran pasar modern.

$$
\begin{aligned}
& P \hat{T}=-47.704-0.070 P_{t}+3.645 P O P_{t} \quad R^{2}=0.8381, M S E=0.0140 \quad \ldots \\
& (-1.33) \quad \text { (2.68) }
\end{aligned}
$$

Hasil estimasi perkembangan jumlah pasar tradisional dipengaruhi oleh jumlah kehadiran pasar modern dan jumlah penduduk Kabupaten Subang. Dari Persamaan (18) dikethaui bahwa perkembangan jumlah pasar modern akan berpengaruh negative terhadap perkembangan jumlah pasar tradisional. Hal ini menunjukkan kedua pasar akan bersaing, dan dari hasil survey diketahui bahwa pasar tradisional kalah bersaing dengan pasar modern. Ini merupakan suatu tantangan bagi pemda melakukan meningkatkan daya saing pasar tradisional dengan salah satu strategi adalah revitaslisai pasar tradisional.

$$
P \hat{A} D=-3.949+0.048\left(P M_{t}+P T_{t}\right)+0.725 G D P_{t} \quad R^{2}=0.8891, M S E=0.0764
$$

Pada Persamaan (19) diketahui bahwa jumlah penerimaan pendapatan asli daerah (PAD) dipengaruhi secara signifikan oleh besarnya PDRB Kabupaten Subang. Selain PDRB, jumlah pasar tradisional dan pasar modern juga ikut mempengaruhi besarnya penerimaan PAD Kabupaten Subang meskipun secara statistic tidak berbeda nyata dengan nol pada taraf kepercayaan 95 persen.

$$
I \hat{N} C_{t}=5.558+0.987 G D P_{t}-1.192 I N F_{t} \quad R^{2}=0.9755, M S E=0.0107
$$


Pada Persamaan (20) diketahui bahwa daya beli masyarakan (diproxy dari pendapatan perkapita Kabupaten Subang) dipengaruhi secara positif oleh PDRB Kabupaten Subang. Sedangkan tingkat inflasi berpengaruh negative terhadap daya beli masyakat kabupaten Subang. Inflasi memberikan dampak negative bagi perkembangan daya beli.

$$
\hat{U}_{t}=12.595-0.136 G D P_{t}+0.053 I N F_{t} \quad R^{2}=0.8516, M S E=0.0066
$$

Hal sama juga terlihat bahwa pada persamaan (21) dimana jumlah pengangguran di Kabupaten Subang dipengaruh secara negative oleh PDRB Kabupaten Subang. Artinya bahwa jika PDRB (pertumbuhan ekonomi) Kabupaten meningkat satu persen maka jumlah pengangguran dapat dikurangi sebesar 1.13 persen. Sedangkan tingkat semakin tinggi tingkat inflasi akan berdampak bagi peningkatan jumlah pengangguran di Kabupaten Subang.

\section{Validasi Model}

Untuk mengetahui apakah model cukup valid untuk membuat suatu simulasi alternatif kebijakan atau non kebijakan, maka perlu dilakukan pengujian terhadap model, dengan tujuan untuk manganalisis sejauhmana model tersebut dapat mewakili fenomena Keberadaan pasar modern terhadap pertumbuhan Usaha Mikro, Kecil dan Menengah.

Dalam kajian ini, kriteria statistik untuk validasi model yang digunakan adalah Root Means Percent Square Error (RMSPE) yang digunakan untuk mengukur seberapa jauh nilai-nilai peubah endogen hasil pendugaan menyimpang dari alur nilai-nilai aktualnya dalam ukuran relatif (persen), atau seberapa dekat nilai dugaan itu mengikuti perkembangan nilai aktualnya, sedangkan Theil's Inequality Coefficient (U), bermanfaat untuk mengetahui kemampuan model untuk melakukan simulasi dan analisis kebijakan. Pada dasarnya makin kecil nilai RMSPE dan U-Theil's, maka pendugaan model semakin baik (Pindyck and Rubinfield, 1991).

Tabel 1. Hasil Ringkasan Validasi Model UMKM Kabupaten Subang

\begin{tabular}{cccccc}
\hline Variable & RMS \% Error & Bias (UM) & Dist (UD) & Covar (UC) & U-Theil \\
\hline Y1 & 0.8762 & 0.00000 & 1.0000 & 1.0000 & 0.0043 \\
Y3 & 3.9917 & 0.01000 & 0.6700 & 0.8500 & 0.0189 \\
Y6 & 1.4220 & 0.00000 & 1.0000 & 0.9600 & 0.0070 \\
GDP & 12.9886 & 0.05000 & 0.6800 & 0.7400 & 0.0450 \\
R1 & 1.2217 & 0.00000 & 0.9900 & 0.9800 & 0.0062 \\
R3 & 1.3406 & 0.00000 & 0.9800 & 0.9900 & 0.0065 \\
R6 & 2.2232 & 0.00000 & 0.9900 & 0.9300 & 0.0108 \\
PT & 3.0026 & 0.00000 & 0.9300 & 0.9900 & 0.0146 \\
PAD & 1.2284 & 0.00000 & 1.0000 & 0.9900 & 0.0062 \\
\hline
\end{tabular}




\begin{tabular}{cccccc}
\hline INC & 1.1112 & 0.01000 & 0.9000 & 0.9600 & 0.0055 \\
$U$ & 0.7608 & 0.00000 & 1.0000 & 0.8700 & 0.0038 \\
\hline
\end{tabular}

Dari Tabel 1 dapat diketahui bahwa seluruh 10 persamaan perilaku nilai RMSPE dibawah 10 persen dan satu persamaan (PDRB) nilai RMSPE adalah 12.98 persen. Hal ini menunjukkan bahwa persamaan perilaku yang hanya menyimpang dibawah 10 persen dari nilai aktualnya, kecuali untuk persamaan PDRB menyimpang sebesar 12.98 persen. Sedangkan dilihat dari nilai Theil's Inequality Coefficient (U), model ini juga dapat dijadikan sebagai sebuah evaluasi model untuk melihat alternatif kebijakan, karena nilai U-Theil seluruhnya berada di bahwa 0.2. Dengan kata lain bahwa, secara keseluruhan model ini dapat digunakan untuk melakukan peramalan perilaku dan simulasi maupun alternatif kebijakan. Dalam kajian ini model digunakan untuk meramalkan, melainkan hanya untuk melihat bagaimana dampak keberadaan pasar modern terhadap kinerja perekonomian Kabupaten Subang pada umumnya dan kinerja UMKM pada khususnya.

\section{Skenario Kebijakan}

Simulasi kebijakan dilakukan yang dengan tujuan untuk menganalisis keberadaan pasar modern terhadap kinerja ekonomi daerah Kabupaten Subang. Beberapa skenario simulasi alternatif kebijakan yang terkait dengan keberadaan pasar modern dan UKM di Kabupaten Subang secara arbitrary, yaitu: (1) Peningkatan jumlah pasar Modern sebesar 10 persen terhadap kinerja perekonomian Kabupaten Subang, dan (2) Peningkatan kredit UMKM sebesar 10 persen terhadap kinerja perekonomian Kabupaten Subang. Berikut adalah uraiannya.

\section{Dampak Keberadaan Pasar Modern Terhadap Kinerja Ekonomi Daerah}

Untuk mengetahui dampak keberadaan pasar modern terhadap pertumbuhan UMKM di kabupaten Subang dilakukan dengan mensimulasikan apabila terjadi peningkatan jumlah pasar modern sebesar 10 persen, maka Output perekonomian (PDRB) mengalami peningkatan sebesar 0,37\% dimana kenaikan ini juga merupakan kontribusi dari output sector pertanian dan sector industry pengolahan yang mengalami kenaikan sebesar $0,453 \%$ dan 2,435\%. Akan tetapi pada sector perdagangan justru mengalami penurunan sebesar 1,039\% sebagai akibat dampak persaingan antara pasar modern dan usaha perdagangan ritel lainnya. Omzet UMKM baik disektor pertanian maupun sector industri pengolahan juga mengalami kenaikan sebesar $0,879 \%$ dan 3,074\%, juga untuk sector perdagangan mengalami penurunan omzet sebesar $1,714 \%$ secara agregat. Hal ini juga sebagai bagian efek dari penurunan jumlah pasar tradisional yang menurun sebesar $0,673 \%$.

Efek dari penurunan output sektor perdagangan dan pasar tradisional berimplikasi juga terhadap penurunan pendapatan asli daerah (PAD) sebesar 0,649\% meskipun terhadap PDRB justru mengalami kenaikan, hal ini dimungkinkan mengingat akibat penurunan pasar tradisional dan sector perdagangan juga mengakibatkan 
hilangnya jenis dan sejumlah pungutan pajak dan retribusi daerah dimana rata-rata pasar tradisional menggunakan aset daerah.

Tabel 2. Dampak Keberadaan Pasar Modern Terhadap Pertumbuhan UMKM Kabupaten Subang

\begin{tabular}{clrrrr}
\hline \multirow{2}{*}{ No } & \multirow{2}{*}{ Variabel } & \multirow{2}{*}{ Satuan } & \multirow{2}{*}{ Nilai Dasar } & \multicolumn{2}{c}{ Simulasi Pasar Modern } \\
\cline { 5 - 6 } & & & \multicolumn{1}{c}{ Nilai } & \multicolumn{1}{c}{$\%$} \\
\hline 1 & Produk Domestik Regional Bruto & Rp Juta & 13124339.0 & 13172876.0 & 0.370 \\
2 & Output Sektor Pertanian & Rp Juta & 5077791.7 & 5100789.0 & 0.453 \\
3 & Output Sektor Industri Pengolahan & Rp Juta & 2092910.5 & 2143879.0 & 2.435 \\
4 & Output Sektor Perdagangan & Rp Juta & 2447317.3 & 2421889.0 & -1.039 \\
5 & Omzet UMKM Sektor Pertanian & Rp Juta & 98477.6 & 99343.1 & 0.879 \\
6 & Omzet UMKM Sektor Industri Pengolahan & Rp Juta & 89050.2 & 91787.8 & 3.074 \\
7 & Omzet UMKM Sektor Perdagangan & Rp Juta & 91743.9 & 90171.5 & -1.714 \\
8 & Pasar Tradisional & Unit & 42.2 & 41.9 & -0.673 \\
9 & Pendapatan Asli Daerah & Rp Juta & 70570689.0 & 70112561.0 & -0.649 \\
10 & Dayabeli (Income Perkapita) & Rp Juta & 5130167.6 & 5148976.0 & 0.367 \\
11 & Pengangguran & Orang & 31418.2 & 31403.1 & -0.048 \\
\hline
\end{tabular}

Disisi daya beli dengan masuknya pasar modern akan menjadikan harga lebih kompetitif dan terjadinya peningkatan PDRB juga akan menjadikan pendapatan perkapita mengalami peningkatan sehingga daya beli masyarakat juga mengalami peningkatan sebesar $0,367 \%$. Tingkat harga-harga yang lebih kompetitif juga dapat meningkatkan investasi sehingga angka pengangguran mengalami penurunan sebesar 0,048\%. Tingkat perubahan-perubahan hasil simulasi untuk mengukur dampak keberadaan Pasar Moder terhadap pertumbuhan UMKM Kabupaten Subang tersebut dapat dilihat pada Table 2.

\section{DAMPAK PENINGKATAN KREDIT UMKM TERHADAP KINERJA EKONOMI DAERAH}

Dengan mensimulasikan pemberian shok peningkatan investasi sebesar 10 persen diperoleh hasil simulasi hampir semua indikator mengalami peningkatan yang cukup signifikan hanya pasar tradisional saja yang konstan tidak mengalami perubahan. Dampak peningkatan investasi ini akan sangat dapat dirasakan pada sector pertanian dimana outputnya mengalami peningkatan mencapai 9,023\% dengan kenaikan omzet UMKM sector pertanian sebesar 2,948\%.

Tabel 3. Dampak Peningkatan Kredit UMKM terhadap Terhadap Kinerja Perekonomian Kabupaten Subang

\begin{tabular}{|c|c|c|c|c|c|}
\hline \multirow{2}{*}{ No } & \multirow{2}{*}{ Variabel } & \multirow{2}{*}{ Satuan } & \multirow{2}{*}{$\begin{array}{l}\text { Nilai } \\
\text { Daar }\end{array}$} & \multicolumn{2}{|c|}{ Nilai Simulasi } \\
\hline & & & & Nilai & $\% \Delta$ \\
\hline 1 & GDP & Rp Juta & 13124339.0 & 13792855 & 5.094 \\
\hline 2 & Output Sektor Pertanian & Rp Juta & 5077791.7 & 5535946 & 9.023 \\
\hline 3 & Output Sektor Industri Pengolahan & Rp Juta & 2092910.5 & 2103316 & 0.497 \\
\hline 4 & Output Sektor Perdagangan & Rp Juta & 2447317.3 & 2647274 & 8.170 \\
\hline 5 & Omzet UMKM Sektor Pertanian & Rp Juta & 98477.6 & 101380.7 & 2.948 \\
\hline
\end{tabular}




\begin{tabular}{clrrrr}
\hline \multirow{2}{*}{ No } & \multirow{2}{*}{ Variabel } & \multirow{2}{*}{ Satuan } & \multicolumn{1}{c}{ Nilai } & \multicolumn{2}{c}{ Nilai Simulasi } \\
\cline { 5 - 6 } & & & \multicolumn{1}{c}{ Daar } & \multicolumn{1}{c}{ Nilai } & $\% \Delta$ \\
\hline 6 & Omzet UMKM Sektor Industri Pengolahan & Rp Juta & 89050.2 & 89073.92 & 0.027 \\
7 & Omzet UMKM Sektor Perdagangan & Rp Juta & 91743.9 & 99038.89 & 7.951 \\
8 & Pasar Tradisional & Unit & 42.2 & 42.19049 & 0.000 \\
9 & Pendapatan Asli Daerah & Rp Juta & 70570689.0 & 73164385 & 3.675 \\
10 & Dayabeli (Income Perkapita) & Rp Juta & 5130167.6 & 5388018 & 5.026 \\
11 & Pengangguran & Orang & 31418.2 & 31205.58 & -0.677 \\
\hline
\end{tabular}

Pada sector perdagangan pun demikian output sector perdagangan dapat mencapai $8,17 \%$ dengan peningkatan omzet UMKM sector perdagangan $7,951 \%$. Secara keseluruhan dapat dijelaskan bahwa peningkatan kredit UKM sebesar 10 memberikan positif bagi kinerja perekonomian Kabupaten Subang (Tabel 3).

\section{PERSEPSI RESPONDEN UKM TERHADAP KEBERADAAN PASAR MODERN}

Keberadaan pasar modern di Kabupaten Subang tidak semua merugikan bagi pelaku UKM. Dari jumlah keseluruhan responden UKM sekitar 79,02\% menyatakan bahwa kehadiran pasar modern tidak memberikan dampak penurunan terhadap omzet penjualan, hanya $20,98 \%$ saja yang menyatakan berpengaruh pada penurunan omzet penjualan. Terhadap UKM sektor pertanian hampir $100 \%$ menyatakan tidak berdampak, namun pada sektor Industri Pengolahan untuk kategori Usaha Kecil dan Menengah 18,42\% dan 9,09\% menyatakan berdampak pada penurunan omzet penjualan. Pernyataan "kehadiran pasar modern memiliki dampak pada penurunan omzet penjualan", lebih banyak terjadi pada sektor perdagangan baik pada Usaha Mikro, Kecil maupun Menengah dengan frekuensi 36,36\%, 50\% dan 41,67\%. Lebih jelasnya dapat dilihat pada Tabel 4.

Tabel 4. Persepsi Dampak Kehadiran Pasar Modern Terhadap Penurunan Omzet Penjualan

\begin{tabular}{llrrr}
\hline \multirow{2}{*}{ Kelompok UMKM } & Sektor & \multicolumn{3}{c}{ Penurunan Omzet } \\
\cline { 3 - 5 } & & \multicolumn{1}{c}{ Ya } & Tidak & Total \\
\hline Mikro & Pertanian & 0.00 & 100.00 & 100 \\
& Industri pengolahan & 0.00 & 100.00 & 100 \\
& Perdagangan & 36.36 & 63.64 & 100 \\
& Pertanian & 0.00 & 100.00 & 100 \\
& Industri pengolahan & 18.42 & 81.58 & 100 \\
& Perdagangan & 50.00 & 50.00 & 100 \\
\hline
\end{tabular}




\begin{tabular}{llrrr}
\hline \multirow{2}{*}{ Kelompok UMKM } & Sektor & \multicolumn{3}{c}{ Penurunan Omzet } \\
\cline { 3 - 5 } & & \multicolumn{1}{c}{ Ya } & \multicolumn{1}{c}{ Tidak } & \multicolumn{1}{c}{ Total } \\
\hline Menengah & Pertanian & 0.00 & 100.00 & 100 \\
& Industri pengolahan & 9.09 & 90.91 & 100 \\
& Perdagangan & 41.67 & 58.33 & 100 \\
\hline Total & & 20.98 & 79.02 & 100 \\
\hline
\end{tabular}

Sumber: Data Survei diolah (2010)

Persepsi ini merupakan persepsi yang merupakan pernyataan langsung dari pelaku usaha UKM di Kabupaten Subang sehingga dapat di justifikasi bahwa kehadiran Pasar Modern dominan menyebabkan dampak penurunan omzet penjualan pada UKM sektor Perdagangan. Hal ini mengindikasikan bahwa UKM sector Perdagangan belum mampu bersaing dengan Pasar Modern atau dengan kata lain UKM sektor Perdagangan di Kabupaten Subang memiliki daya saing yang masih rendah.

Dari 20,98\% UKM yang menyatakan kehadiran pasar modern memiliki dampak penurunan terhadap omzet penjualan untuk sektor Perdagangan menyatakan ratarata penurunan omzetnya sebesar $25 \%$ pada Usaha Mikro, 22,48\% pada Usaha Kecil dan $21,60 \%$ pada Usaha Menengah. Besaran Tingkat penurunan omzet dari mulai Usaha Mikro hingga Menengah memiliki kecenderungan menurun, hal ini mengindikasikan bahwa terdapat kemungkinan besar penurunan omzet penjualan pada sector perdagangan tersebut ditentukan juga oleh skala ekonomi (the economies of scale) produksinya. Akan tetapi hal ini tidak berlaku pada sektor Industri Pengolahan dimana untuk Usaha Mikro pada sector ini menyatakan tidak berdampak sementara pada Usaha Kecil menyatakan berdampak penurunan omzet penjualan rata-rata sebesar $36,43 \%$ dan pada Usaha Menengah $40 \%$. Perilaku ini dapat disebabkan oleh berbagai kemungkinan seperti Orientasi Target pasar yang sangat bervariasi dan juga harga serta mutu produk/komoditas yang belum mampu bersaing dengan produk/komoditas yang dipasarkan di Pasar Modern.

Kondisi ini harus dicermati secara mendalam dan tidak dapat di justifikasi begitu saja karena apabila dilihat dari kuantitas jumlah unit usaha di sector industri pengolahan hanya sekitar $18,42 \%$ unit usaha kecil yang menyatakan mengalami penurunan omzet penjualan rata-rata $36,43 \%$ dan 9,09 unit usaha menengah yang menyatakan mengalami penurunan omzet penjualan rata-rata $40 \%$. Bila dibandingkan dengan yang menyatakan tidak yaitu $81,58 \%$ unit Usaha Kecil dan 90,91\% unit usaha menengah pada sector Industri, menjadikan pernyataan yang menyatakan berdampak menjadi tidak begitu berarti. Secara keseluruhan dapat disimpulkan bahwa indikasi kuat kehadiran pasar modern memberikan dampak penurunan omzet penjualan hanya pada sector Perdagangan baik untuk Usaha Mikro, Kecil ataupun Menengah (Tabel 5). 
Tabel 5. Besaran Tingkat Penurunan Omzet Penjualan Akibat Kehadiran Pasar Modern Berdasarkan Sektor

\begin{tabular}{llcr}
\hline \multirow{2}{*}{ UKM } & \multicolumn{1}{c}{ Sektor } & \multicolumn{2}{c}{ Penurunan Omzet (Rp Juta) } \\
\cline { 3 - 4 } Mikro & Pertanian & 0.00 & Jumlah \\
& Industri pengolahan & 0.00 & 0.00 \\
\multirow{3}{*}{ Kecil } & Perdagangan & 25.00 & 0.00 \\
& Pertanian & 0.00 & 100.00 \\
& Industri pengolahan & 36.43 & 0.00 \\
Menengah & Perdagangan & 22.48 & 255.00 \\
& Pertanian & 0.00 & 292.20 \\
& Industri pengolahan & 40.00 & 0.00 \\
& Perdagangan & 21.60 & 40.00 \\
& & & 108.00 \\
\hline
\end{tabular}

Sumber: Data Survei diolah (2010)

Dampak penurunan terhadap omzet penjualan untuk kelompok usaha mikro terjadi di tiga (3) zona yaitu utara, selatan dan barat, dengan besaran masing-masing sebesar 25\%. Sementara untuk zona tengah tidak terjadi penurunan omzet. Selanjutnya untuk usaha kecil, penurunan omzet terjadi diseluruh zona, dengan penurunan omzet terbesar terjadi di zona selatan dengan besaran $75 \%$ diikuti oleh zona barat dengan besaran 38,50\%, zona tengah dengan besaran $30 \%$ dan terkecil di zona utara dengan besaran hanya $11,17 \%$.

Penurunan omzet usaha menengah terjadi di tiga (3) zona yaitu di zona tengah, selatan dan barat, berturut- turut sebesar 40\%, 33,33\% dan 4\%. Hasil kajian ini menjelaskan bahwa daya saing UMKM secara keseluruhan antar zona cukup bervariasi dimana di zona utara relatif lebih baik dibanding tiga zona lainnya. Daya saing UMKM yang relative paling lemah yaitu ada di zona selatan. Keragaman daya saing mungkin berkaitan dengan bervariasinya kemampuan UMKM antar zona dalam mengelola usahanya seperti dalam hal memilih jenis produk yang diperdagangkan, penentuan harga produk dan system pelayanan terhadap pelanggan.

\section{KESIMPULAN DAN IMPLIKASI KEBIJAKAN KESIMPULAN}

Dari hasil analisis terhadap data survey dan model secara singkat dapat ditarik kesimpulan terkait keberadaan pasar modern terhadap UKM antara lain sebagai berikut:

1. Kehadiran pasar modern memberikan pengaruh yang negative terhadap UMKM sector perdagangan, sebaliknya terhadap sektor pertanian dan sektor industry pengolahan saling melengkapi. Kehadiran pasar modern secara langsung akan berkompetisi dengan UMKM sektor perdagangan, dan dalam hal ini omzet UKM sector perdagangan akan menurun pada kisaran $21,6 \%$ hingga $25,0 \%$.

2. Pada sektor Industri pengolahan kehadiran pasar modern akan memunculkan persaingan dalam harga dan mutu produk yang dijual, dimana harga dan mutu produk UMKM Kabupaten Subang relative kurang mampu bersaing secara seimbang dengan harga dan mutu produk yang dijual di pasar modern. 
3. Sementara pada sektor pertanian kehadiran pasar modern justru sama sekali tidak memberikan dampak negatif. Hal ini diperkuat dengan hasil persepsi responden pasar modern yang memasarkan produk UKM, dimana sebagian besar produk didominasi oleh produk pangan pertanian dan lanjutannya.

4. Ditinjau dari kemampuannya menyerap tenaga kerja Pasar Modern dapat dikatakan tidak terlalu banyak menyerap tenaga kerja meskipun dengan kecenderungan semakin besar omzetnya penyerapan tenaga kerjanya semakin meningkat, karena bila dibandingkan dengan UKM sector industry pengolahan yang bisa mencapai 53 orang per-unit usaha pada Usaha Menengah Sektor industri pengolahan.

5. Dari aspek Kelembagaan, sekitar $80,42 \%$ UKM di Kabupaten Subang merupakan usaha perorangan dan hanya berkisar $19,58 \%$ saja UKM yang merupakan badan hukum, hal ini dapat menggambarkan bahwa UKM di Kabupaten Subang dalam aspek kelembagaannya belum terkelola dengan baik dari aspek manajemen. Hal ini juga berkaitan dengan kemampuannya untuk mendapatkan akses permodalan dan akses untuk masuk menuju pasar formal dimana kondisi ini menjadi salah satu constraint.

6. Hasil Produksi UMKM Kabupaten Subang hanya dijual di pasar Modern Sebesar 1.36 persen dari total omzet pasar Modern, hal ini menunjukkan bahwa pasar Modern enggan menjual produk local dari pelaku UMKM.

7. Dari Aspek Regulasi, rata-rata Pasar Modern yang turut memasarkan produk UKM di kabupaten Subang di dominasi oleh pasar modern lokal sementara untuk pasar modern yang merupakan wara laba umumnya tidak memasarkan produk UKM local, karena jenis barang/produk ditentukan oleh cabang. Regulasi yang demikian merupakan salah satu hambatan UKM untuk memasarkan produknya di Pasar Modern. Hal ini mengindikasikan bahwa di Kabupaten Subang belum menerapkan Peraturan Menteri Perdagangan Republik Indonesia Nomor : 53/MDAG/PER/12/2008 tentang Pedoman Penataan dan Pembinaan Pasar Tradisional, Pusat Perbelanjaan dan Toko Modern.

8. Implementasi kebijakan penataan pasar di Kabupaten Subang saat ini masih belum berjalan secara efektif hal mana ditunjukkan oleh letak pasar tradisional dan pasar modern yang belum tertata dengan baik, dan saat ini jumlah pasar modern semakin menjamur sampai ke pelosok kecamatan.

9. Skenario peningkatan akses terhadap modal berupa pemberian kredit UMKM berdampak pada peningkatan kinerja ekonomi Kaupaten Subang, yang digambarkan oleh peningkatan pertumbuhan ekonomi dan penurunan jumlah penganggaran di Kabupaten Subang.

10. Skenario peningkatan unit pasar modern berdampak pada kenaikan pertumbuhan ekonomi dan penurunan jumlah pengangguran. Namun sector perdagangan justru mengalami penurunan yang diduga karena persaingan antara pasar modern dan usaha perdagangan ritel lainnya. Sementara omzet UMKM baik disektor pertanian maupun sector industri sebaliknya untuk sektor perdagangan. Pengaruh penurunan output sektor perdagangan dan pasar tradisional berimplikasi juga terhadap penurunan pendapatan asli daerah (PAD) karena akan mengakibatkan 
hilangnya jenis dan sejumlah pungutan pajak dan retribusi daerah dimana rata-rata pasar tradisional menggunakan aset daerah

\section{IMPLIKASI KEBIJAKAN}

Berdasarkan kesimpulan hasil analisa data primer dan permodelan makro ekonomi pengukuran pengaruh keberadaan pasar modern terhadap tingkat pertumbuhan UKM di Kabupaten Subang tersebut maka dapat direkomendasikan beberapa kebijakan terkait antara lain sebagai berikut: Dalam rangka untuk mengurangi dampak negative dari keberadaan pasar modern, maka pemerintah Kabupaten Subang harus mampu mengendalikan pertumbuhan Pasar Modern agar berkorelasi postif terhadap output sector perdagangan, omzet UMKM Sektor Perdagangan, Pasar Tradisional maupun PAD. Untuk dapat menghasilkan kondisi demikian dapat dilakukan dengan cara meminimalisir efek persaingan antara Pasar Modern dengan pelaku sektor perdagangan lainnya terutama Pasar Tradisional dan UMKM sector perdagangan. Upaya untuk itu dapat dicapai dengan suatu pendekatan Program ataupun Regulasi Kemitraan diantara pelaku usaha sektor perdagangan dan juga dengan pendekatan strategi memanfaatkan aglomerasi positif dari keberadaan Pasar. Pemberian Kredit terhadap UMKM harus lebih ditingkatkan. Salah satu cara untuk meningkatkan kredit UMKM tersebut adalah dengan strategi memberikan kemudahan akses pelaku usaha UMKM dalam memperoleh Kredit Usaha dan stimulan.

Ditinjau dari aspek daya saingnya terlihat bahwa UMKM sektor perdagangan tidak mampu bersaing dengan Pasar Modern dan juga kemampuan permodalan UMKM sektor perdagangan jauh lebih rendah dari pada Pasar Modern sehingga rekomendasi terbaik adalah mengarahkan pelaku UMKM perdagangan untuk pendiferensiasian produk sehingga UMKM sektor perdagangan tidak bersaing dengan Pasar Modern. Selain dari pada hal pengembangan pasar modern sudah perlu dilkendalikan salah satunya adalah mengarahkan pengembangan pasar modern ke zona utara dan barat yang tingkat persaingannya belum tinggi serta meningkatkan daya saing UMKM sektor perdagangan pada zona yang belum terdapat pasar modern agar lebih kompetitif sebelum Pasar Modern dikembangkan. Untuk meningkatkan daya saing UMKM secara umum perlu juga untuk diberikan program pembinaan pengembangan dan standarisasi mutu produk/komoditas.

Dalam hal penyerapan tenaga kerja, UMKM sektor industri pengolahan memiliki tingkat penyerapan tenaga kerja yang sangat baik sehingga perlu dilakukan proteksi dengan pemberian insentif seperti pengurangan jumlah besaran pungutan pajak dan retribusi yang mengena pada UMKM sektor industri pengolahan tersebut. Selain dari pada itu UMKM sektor industri pengolahan yang berkaitan erat dengan sektor pertanian perlu lebih dikembangkan karena memiliki kontribusi yang sangat positif baik terhadap sektor pertanian dan juga sektor perdagangan. UMKM yang berada di Kabupaten Subang umumnya merupakan usaha perorangan yang belum berbadan hukum, hal ini menyebabkan akses UMKM tersebut untuk masuk ke dalam pasar formal masih terbatas juga dalam hal manajemen yang belum professional. Untuk itu rekomendasi kebijakannya adalah dengan program peningkatan kapasitas SDM dalam hal manajerial usaha juga bantuan Pemerintah untuk mendapatkan kemudahan dalam hal kepengurusan administrasi badan usaha. Untuk aspek 
pembiayaan dan permodalan terlihat bahwa UMKM di Kabupaten Subang masih sangat membutuhkan Pemberian Kredit Modal Kerja maupun kredit usaha kerja yang sesuai dengan orientasi pasar yang potensial sesuai bidang usahanya.

Dari sisi aspek regulasi perlu lebih mengefektifkan kembali penerapan Peraturan Menteri Perdagangan Republik Indonesia Nomor : 53/M-DAG/PER/12/2008 tentang Pedoman Penataan dan Pembinaan Pasar Tradisional, Pusat Perbelanjaan dan Toko Modern untuk meningkatkan kemitraan UMKM dan Pasar Modern serta menata kembali ruang untuk aktifitas pasar modern dalam Rancan Tata Ruang Wilayah dan Rencana Detail Tata Ruang serta Zonasi Kabupaten Subang.

\section{DAFTAR PUSTAKA}

Agresti, A. and B. Finlay, 1999. Statistical Methods for the Social Sciences. Third Edition. Prentice Hall, Upper Saddle River, New Jersey.

Badan Pusat Statistik. 2009. Subang Dalam Angka 2009. Badan Pusat Statistik Kabupaten Subang.

Badan Pusat Statistik. 2009. Subang Dalam Angka 2009. Badan Pusat Statistik Kabupaten Subang.

Dinas Koperasi dan Usaha Mikro, Kecil dan Menengah Kabupaten Subang. 2008. Direktori Usaha Kecil Menengah Kabupaten Subang Tahun 2008. Dinas Kopersai UMKM Kabupaten Subang.

Dinas Koperasi dan Usaha Mikro, Kecil dan Menengah Kabupaten Subang. 2009. Direktori Usaha Kecil Menengah Kabupaten Subang Tahun 2009. Dinas Kopersai UMKM Kabupaten Subang.

Dinas Koperasi dan Usaha Mikro, Kecil dan Menengah Kabupaten Subang. 2008. Direktori Usaha Kecil Menengah Kabupaten Subang Tahun 2008. Dinas Kopersai UMKM Kabupaten Subang.

Dinas Koperasi dan Usaha Mikro, Kecil dan Menengah Kabupaten Subang. 2009. Direktori Usaha Kecil Menengah Kabupaten Subang Tahun 2009. Dinas Kopersai UMKM Kabupaten Subang.

Intriligator, M. D. 1978. Econometric Model, Techniques, and Applications. Prentice Hall Inc, New Jersey.

Koutsoyiannis, A. 1977. Theory of Econometrics: An Introductory Exposition of Econometic Methods. Second Edition. The MacMillan Press Ltd, London

Nielson, C. 2003. Modern Supermarket (Terjemahan AW Mulyana). Fakultas Ekonomi Universitas Indonesia. Jakarta : Universitas Indonesia.

Pindyck, R. S. and D. L. Rubinfeld. 1991. Econometric Models and Economic Forcasts. Third Edition. McGraw-Hill Inc, New York.

Sinaga, Pariaman. 2004. Makalah Pasar Modern VS Pasar Tradisional. Kementerian Koperasi dan UKM. Jakarta.

Suryadharma, D., A. Poesoro., S. Budiyati., Akhmadi., dan M. Rosfadhila. 2007. Dampak Supermarket terhadap Kebijakan Pasar dan Pedagang Ritel Tradisional di Daerah Perkotaan di Indonesia. Lembaga Penelitian SMERU.

Weiss, N. and M. Hassett. Introductory Statistics. Addison-Wesley. Publishing Company, Inc. Philippines. 